\title{
IS THERE AN IDEAL AGE TO WIN AN OLYMPIC MEDAL?
}

\section{Authors:}

Ildikó Balatoni (Med., PhD)

University of Debrecen (Hungary)

Ágnes Jenes (Med., PhD)

University of Debrecen (Hungary)

Nikolett Kosztin (Med.)

University of Debrecen (Hungary)

László Csernoch (Prof., PhD, doctor of MTA)

University of Debrecen (Hungary)

E-mail address of the first author:

balatoni@med.unideb.hu

\section{Lectors:}

Beatrix Dienes $(\mathrm{PhD})$

University of Debrecen (Hungary)

János Magyar (Prof., PhD, doctor of MTA)

University of Debrecen (Hungary)

Balatoni, I., Jenes, Á., Kosztin, N. \& Csernoch, L. (2020). Is There an Ideal Age to Win an Olimpic Medal? Különleges Bánásmód, 6. (1). 7-17. DOI 10.18458/KB.2020.1.7

\begin{abstract}
Knowledge of the age at which elite athletes achieve peak performance could provide invaluable information for the athletes to plan their career, to carefully select sports events promising successful participation. We aimed to identify the age at which top athletes achieved their Olympic medals, and to observe any changes in the average medal-winning age over the last decades. The age of Olympic medallists between 1960 Rome and 2016 Rio were collected using an online database. Data were gathered from the following individual sports: track and field, swimming, fencing (foil, épée, saber), triple jump, long jump, high jump, and wrestling (57 events all together). The study evaluates and compares the trends in the age of the winners in each discipline. Disciplines of this study show one of the two trends: the trend of increasing age, or trend of decreasing in age. In those disciplines, in which the Olympic medallists were younger than 26 years at the beginning of the examination period, such as swimming, the medallists became older over the decades. In those disciplines, however, in which the top three were older than 26 years at the beginning of the examination period, such as fencers, younger and younger athletes won their Olympic medals as time went by. The age and the trend in the changes of the age of the medallists in the examined disciplines support the theory of an optimal age, being around 26 years.
\end{abstract}

Keywords: Olympic medallists; peak performance; 26 years; optimal age; individual sports

Disciplines: sports science 


\section{Absztrakt \\ MELY ÉLETKORBAN A LEGVALÓSZÍNŰBB EGY OLIMPIAI ÉREMSZERZÉS?}

Annak ismerete, hogy egy sportoló milyen idős korában éri el teljesítőképessége maximumát, fontos szempont lehet a sportolói karrier tervezésében, illetve azon sportesemények kiválasztásában, melyeken a sportoló eredményesen vehet részt. Munkánk során - az utóbbi évtizedek olimpiai versenyeinek eredményeit felhasználva - azt az életkort kívántuk azonosítani, amikor a sportolók eséllyel indulnak olimpiai érmek megszerzéséért. Az elemzéshez az 1960-ban Rómában és a 2016-ban Rio de Janeiroban rendezett olimpiák közötti összes olimpia éremszerzőinek online adatbázisokban elérhető adatait használtuk fel. A következő egyéni sportágakat értékeltük: futás, úszás, vívás (kard, tőr, párbajtőr), hármasugrás, magasugrás, távolugrás és birkózás, összesen 57 versenyszám. Vizsgáltuk, hogy megfigyelhető-e valamilyen trend az éremszerzők életkorának változásában. Megállapítottuk, hogy mind emelkedő, mind csökkenő életkori trendek azonosíthatók, mégpedig úgy, hogy azon sportágak esetén, ahol az éremszerzők a vizsgált periódus elején 26 évnél fiatalabban voltak - úszás, futás -, ott az átlagos életkor emelkedése, míg amennyiben 26 évnél idősebbek voltak - vívás -, ott annak csökkenése volt igazolható. Összességében megállapítható, hogy a vizsgált versenyszámok esetén a 26 éves életkor tekinthető optimálisnak az olimpiai éremszerzés szempontjából.

Kulcsszavak: olimpiai érmesek, csúcsteljesítmény, optimális életkor, egyéni sportágak

Diszciplina: sporttudomány

\section{INTRODUCTION}

The modern Olympic Games, held every four years with more than 200 nations participating, are considered to be the world's most prestigious sports competition. Olympic medallists are flowers of the nations, they are held in high regard and everyone respects them. Since the number of participants is strictly limited (only qualified competitors can enter for Olympic events), Olympic Games often serve as milestones in an athlete's life.

Knowledge of the age at which elite athletes achieve peak performance could provide invaluable information for the athletes, their coaches, and their clubs to plan a career, to carefully select events and to make strategic decisions regarding resource allocation. Adequate information about incidental variances between the age of peak com- petitive performance for different sports and events might help the athlete who is over the hill for a „young sport" to switch to another discipline where his peak performance is yet to be reached.

The physiological parameters characterizing human capacities follow a biphasic pattern: performance is limited at birth, increases to a maximum and then decreases back to zero at death (Berthelot et al, 2012). Both physical and intellectual skills follow such a pattern, except, of course, when injuries, illness, or amnesia ad interim impair certain capabilities, which might favourably regained afterwards. Various biological capacities typically reach their peak at different stages of an individual's life (Simonton, 1988). It would, therefore, be reasonable to assume that the age of peak competitive performance varies between athletes from different 
sports and events, depending on the specific skills and attributes required for success in a particular event.

Sports can be divided into three event-type categories on the basis of the predominant attributes (explosive power/sprint, endurance, and mixed/ skill) required for success in the given event (Allen and Hopkins, 2015). In certain sports or events, such as discus throw, javelin throw, $100 \mathrm{~m}$ track and field or $50 \mathrm{~m}$ swimming, performance is mainly determined by explosive power or sprint. Marathoners, ultra-cyclists, triathletes, or long-distance swimmers, on the other hand, mainly require endurance to perform. Mixed skills (such as slickness, suppleness, anticipation, etc.) limit the top peformance of the fencers, golf, or tennis players (Allen and Hopkins, 2015). In some disciplines the key to success is beyond the possibility to predict. Other than individual capabilities, the success in team sports is further influenced by harmony and trust among the players, knowing each other's strengths and weaknesses. In case of sports requiring special equipment the effects of the technological advances (such as reduction in weight and in resistance of the bikes) cannot be excluded. Not to mention judgement-based sports, including figureskating, gymnastics, and combat sports, where the performance would be difficult to connect to the racer exclusively.

The first systematic review on the topic of age of peak competitive performance of elite athletes concluded that the age of peak performance depended on the duration of the event (Allen and Hopkins, 2015). In explosive power/sprint events, younger athletes performed better in longer competitions: in athletics throws (taking 1-5 s only) top performance is estimated at 27 years, while in short distance swimming $(50 \mathrm{~m}, 100 \mathrm{~m}, 200 \mathrm{~m}$ distances, taking 21-215 s) best results can be expected from 20 -years-old competitors. Conversely, estimates for endurance events increased with increasing event duration. The longer the event, the older the age of peak performance is estimated: in 2-15 min swimming (200-1500 $\mathrm{m}$ distances) competitors at the age around 20 years perform the best, while in events longer than a day (such as ultra-distance cycling) the peak performance is shifted towards 39 years. A possible interpretation of these observations is that to each event-duration in each sport corresponds an ideal age, when the chances of winning culminate. According to Allen and Hopkins (Allen and Hopkins, 2015), the linearly decreasing estimates with increasing event duration for explosive power/sprint events and the linearly increasing estimates with increasing event duration for endurance events reverse at the age of 21 years and events of 4 min duration. They have found insufficient data to investigate trends for mixed/skill events.

Sport performances showed strong development over the last century (Berthelot et al, 2008), world records break every other day, thanks to a myriad of factors. Rising trends can be explained by training methods becoming more and more effective, by wider range of modern sportswear and equipment becoming available, by the number of sport facilities increasing, by conscious nutrition strategies and by the number of competitors increasing by leaps and bounds. This development seems to be slowing down recently, suggesting that a limit is soon to be reached, beyond which the performance cannot be sharpened any further.

In 2008 it was predicted that half of the world records will practically not be broken anymore (the improvement will not exceed $0.05 \%$ by 2027 ; 4). In light of this the topic of age of peak performance has become the focus of considerable research interest across many sports and disciplines (Allen and Hopkins, 2015).

The progressive development of sport performances over the last decades raises the question as to how the population concerned has been altered, whether or not some definable, measurable characteristics - such as age - of the top athletes contrib- 
uting the ascending performance could be identified. The aims of this research have been to identify the age at which top athletes achieved their Olympic medals, and to observe any changes of the average medal-winning age over the past 56 years.

\section{MATERIAL AND METHODS}

For this research, the age of Olympic medallists between 1960 Rome and 2016 Rio were collected using online database, the official website of the Olympic Games (https://www.olympic.org/). Sports and disciplines were selected in our study by the following inclusion and exclusion criteria.

Inclusion criteria:

- featured as Olympic event

- individual

- at least 10 competitions between 1960 and 2016

Exclusion criteria:

- disciplines requiring equipment, where the technological development might have a strong influence on the performance (shooting, pentathlon, cycling, canoe sprint, rowing)

- disciplines where the ranking depends on the judges' scores (gymnastics artistic, diving)

- disciplines where doping is repeatedly confirmed (weightlifting, boxing)

- equestrian (equestrian dressage, equestrian eventing, equestrian jumping)

The following sports were chosen: track and field, swimming, fencing (foil, épée, sabre), triple jump, long jump, high jump, and wrestling. In track and field, nearly the full range of Olympic distances were covered: the $100 \mathrm{~m}, 200 \mathrm{~m}, 400 \mathrm{~m}, 800 \mathrm{~m}$, 1,500 m, 5,000 m, 10,000 $\mathrm{m}$ and marathon; hurdles $100 \mathrm{~m}(\mathrm{~F}), 110 \mathrm{~m}(\mathrm{M}), 400 \mathrm{~m}$ (M, F); steeplechase $000 \mathrm{~m}(\mathrm{M})$. Altogether twenty events were chosen

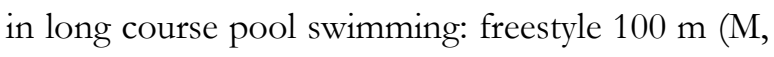
F), $200 \mathrm{~m} \mathrm{(M,} \mathrm{F),} 800 \mathrm{~m}(\mathrm{~F})$ and 1,500 m (M); breaststroke $200 \mathrm{~m}$ (M, F) and $400 \mathrm{~m}$ (M, F); backstroke $100 \mathrm{~m} \mathrm{(M,} \mathrm{F)} \mathrm{and} 200 \mathrm{~m} \mathrm{(M,} \mathrm{F);} \mathrm{overhand}$ stroke $100 \mathrm{~m} \mathrm{(M,} \mathrm{F)} \mathrm{and} 200 \mathrm{~m}$ (M, F); medley 200 $\mathrm{m}(\mathrm{M}, \mathrm{F})$.

In the statistical analysis the age of all three medallists (gold, silver, and bronze) were unweighted, all data contributed equally to the results without considering the place. Average age of the genders were compared using Student's t-test and MannWhitney nonparametric test.

Evaluation of the trends in age of the winners in each discipline were performed using analysis of variance (ANOVA) and Kruskal-Wallis one-way analysis of variance. Comparisons between the average age in 1960 and in 2016 are based on the predicted values using linear regression. Figures were created using SigmaPlot 12 software (Systat Software Inc.).

\section{RESULTS}

The average age of Olympic medal winners varies between disciplines and events. Swimmers are the youngest (20.9 \pm 0.1 years), followed by the athletes (being 4.7 years older than the swimmers), and fencers win their medals at the age of $27.2 \pm 0.3$ years. In some disciplines there are significant differences between the medal winning age of men and women.

In nearly all swimming events men are significantly older then women $(200 \mathrm{~m}$ freestyle is the only exception).

In $1500 \mathrm{~m}$ track and field and in high jump women are significantly older then men. Olympic medallist fencer men and women are of similar age.

The changes in the age of the medallists across Olympic Games show differences between various disciplines and events. Swimmers generally win their gold, silver and bronze medals at older age over time (Figure 1). 
Figure 1. Changes in the age of the top three male and female swimmers in the Olympic Games between 1960 and 2016. a: $100 \mathrm{~m}$ backstroke male, b: $200 \mathrm{~m}$ backstroke male, c: $100 \mathrm{~m}$ backstroke female, d: $200 \mathrm{~m}$ backstroke female. Values are presented as individual data $(\bullet$ first place,
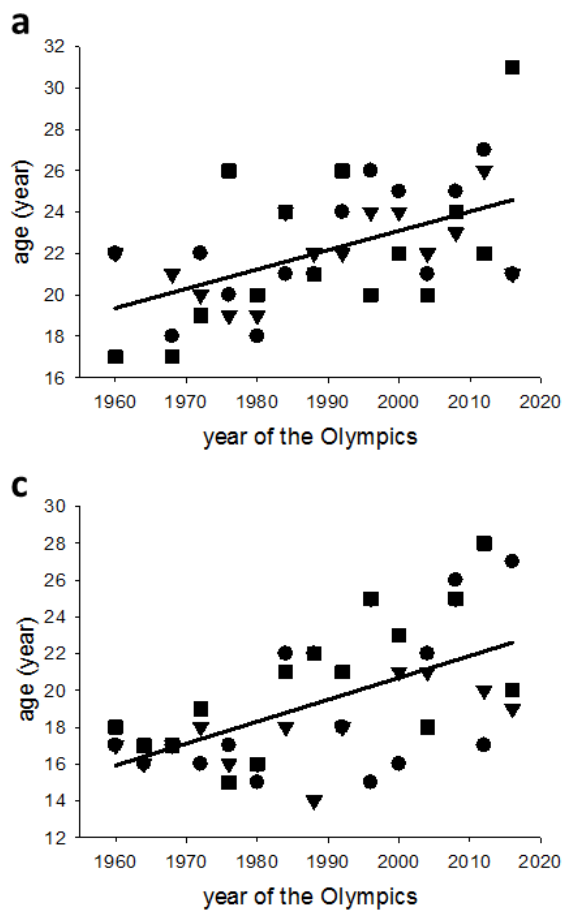

For example, the predicted age of the women's $100 \mathrm{~m}$ backstroke medallists was 15.9 years in 1960 , which increased to 22.6 years by 2016 . The predicted age of the men's $100 \mathrm{~m}$ backstroke medallists increased from 19.4 years in 1960 to 24.6 years in 2016.

The trend of increasing age showed in every swimming events studied. By 2016, the average age in Olympic swimming events approximated 22-23 years for women, and 24-25 years for men. Similar to swimming events, trend of increasing in age was observed in short distance running events (Figure 2). While the predicted age of women's $100 \mathrm{~m}$ track and field medallists was 21.3 years in 1960, it increased to 29.1 years by 2016 . The predicted age of men's $100 \mathrm{~m}$ track and field medallists was 23.5 third place) with linear regression.
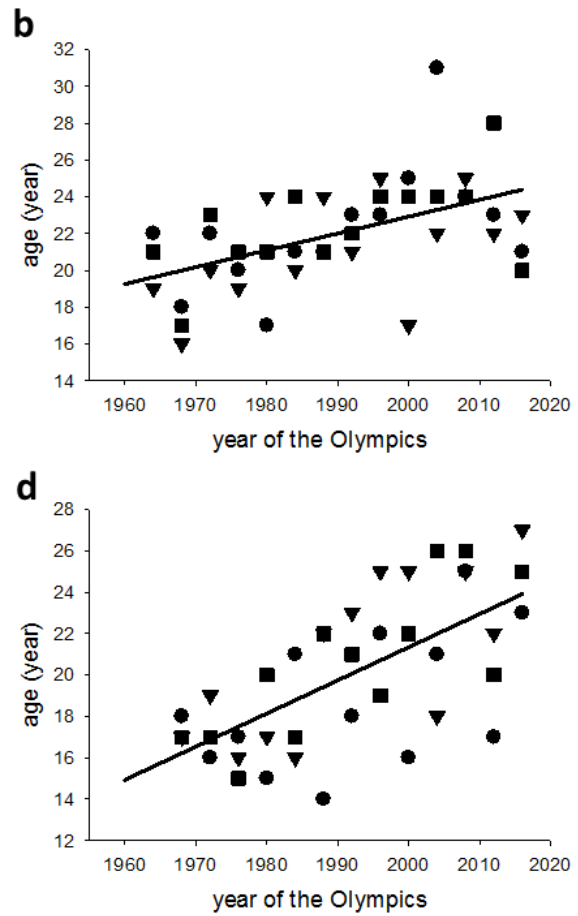

years in 1960, and it increased to 26.9 years by 2016. The average age of the top short distance runners appears to approximate 26-28 years.

In triple jump, long jump, and high jump events, where the Olympic medallists were younger than 26.1 years in 1960 , the average age of the top three increased in both genders, similar to swimmers, and short distance runners. Studying the age of long distance runners revealed, however, a reverse tendency compared to the changes observed in the age of swimmers, short distance runners, or jumpers. The Olympic medallist marathon runners were 28.9 years old in 1960, and 27.6 years old in 2016 . The predicted age of men's $10 \mathrm{~km}$ track and field medallists was 27.9 years in 1960, and it decreased to 24.7 years by 2016 (Figure 3). 
Figure 2. Changes in the age of the medallists in male (a) and female (b) runners (100 $m$ distance) in the Olympic Games between 1960 and 2016. Values are presented as individual data (• first place, $\boldsymbol{\nabla}$ second place, $\mathbf{\square}$ third place) with linear regression.
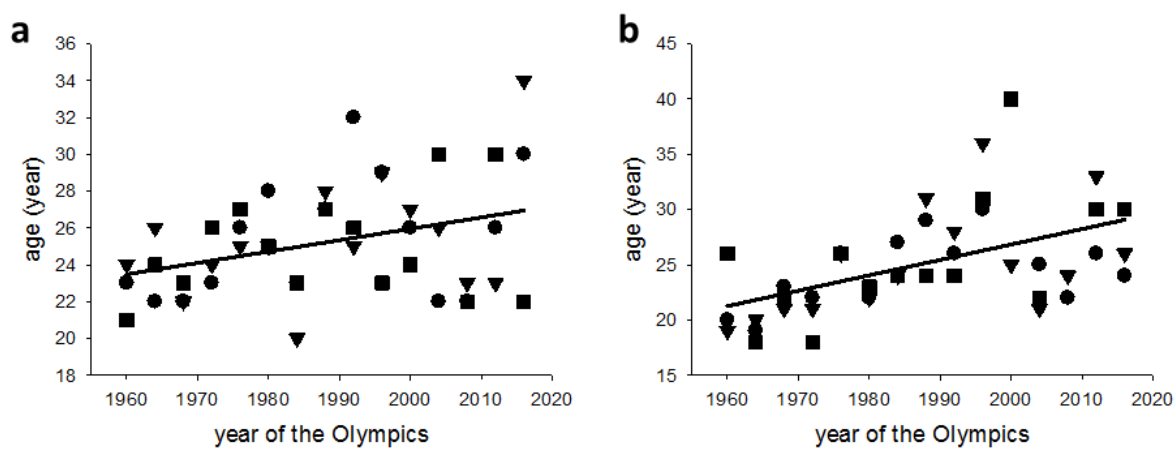

Figure 3. Changes in the age of the medallists in male sabre (a) and male marathon (b) in the Olympic Games between 1960 and 2016. Values are presented as individual data (• first place, $\boldsymbol{\nabla}$ second place, $\mathbf{\square}$ third place) with linear regression.

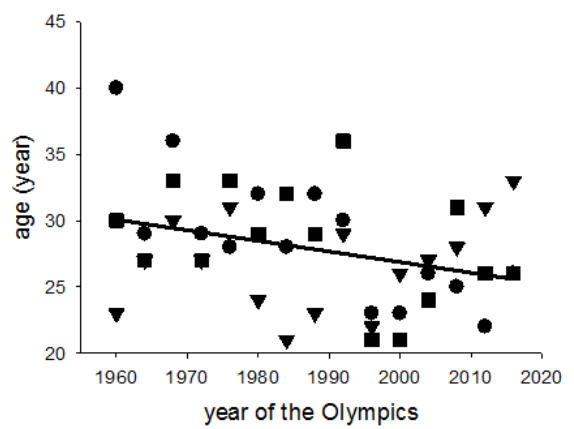

In those running events, where the predicted age of the top three was older than 26 years in 1960 , the age of the Olympic medallists shifts towards younger ages by 2016. Similar trends can be observed in the age of sabreurs (Figure 3). The average age of the top three male sabre fencers decreased from 30.1 years (1960) to 25.6 years (2016).

In summary, disciplines of this study form two groups. In those disciplines, in which the Olympic medallists were younger than 26.1 years at the beginning of the examination period (44 disciplines altogether), the medallists became older over the

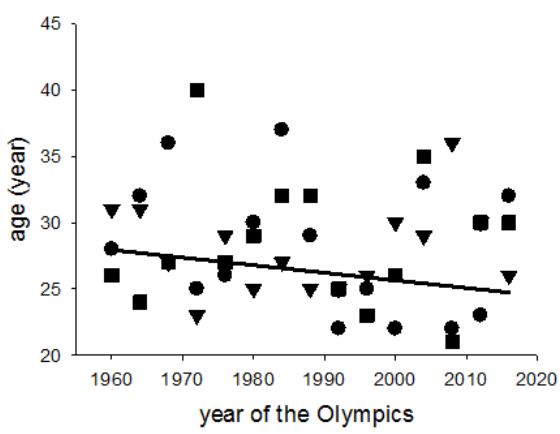

decades. The only exceptions are male $800 \mathrm{~m}$ track and field (from 25.1 years to 24.4 years), female $800 \mathrm{~m}$ track and field (from 25.9 years to 25.6 years) and wrestling flyweight (from 25.9 years to24.8 years).

In those 13 disciplines, however, in which the top three were older than 26.1 years at the beginning of the examination period, younger and younger athletes win their Olympic medals as time goes by. Only exception is male wrestling super heavyweight (from 26.6 years to 27.0 years, Figure 4). 
Figure 4. Changes in the age of the medallists in the Obmpic Games between 1960 and 2016. Each solid line represents a discipline of the followings: female freestyle $100 \mathrm{~m}, 200 \mathrm{~m}, 800 \mathrm{~m}$, backstroke $100 \mathrm{~m}, 200 \mathrm{~m}$, breaststroke $200 \mathrm{~m}, 400 \mathrm{~m}$, overhand stroke 100 m, 200 m, medley 200 m; female running 100 m, 200 m, 400 m, 800 m, 1500 m; female burdles 100 m, 400 m; female high jump, long jump; female foil fencing; male freestyle 100 m, 200 m, 1500 m, backstroke 100 m, 200 m, breaststroke 200 m, 400 m, overhand stroke 100 m, 200 m, medley 200 m; male running 100 m, 200 m, 400 m, $800 \mathrm{~m}, 1500 \mathrm{~m}, 5000 \mathrm{~m}, 10,000 \mathrm{~m}$, marathon; male steeplechase $3000 \mathrm{~m}$; male burdles $110 \mathrm{~m}, 400 \mathrm{~m}$; male triple jump, high jump, long jump; male foil fencing, épée fencing, sabre fencing; male wrestling flyweight, lightweight, welterweight, middleweight, heavyweight and super heavyweight. The dotted line shows 26.1 years of age.

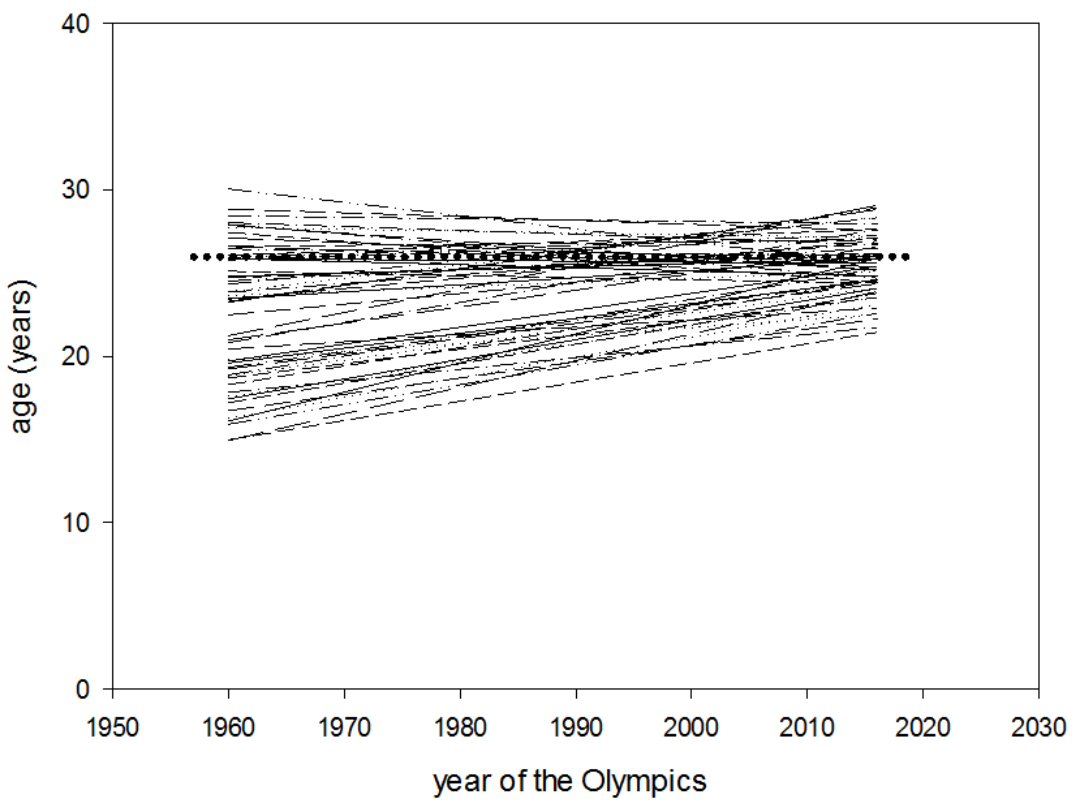

\section{DISCUSSION}

The physiological parameters characterizing human capacities show a biphasic development of growth and decline. Physical and intellectual skills evolving after birth correlate with biolo-gical development, with growing of the body and with learning. Sport performances are influenced by anthropometric data (such as height, body mass index or body fat percentage), speed, strength, slickness, age at specialization, intensity, length and frequency of the trainings, and a series of factors. The development of some capacities can be highly enhanced by learning, by practice or by experience, while other skills are hard to influence by such actions.
The contribution of these easy-to-improve skills and hard-to-influence capacities to the success of an elite athlete likely depends on the sporting event.

This sight exceedingly explains Allen's and Hopkins' (2015) observation, that in the shortest events requiring mostly explosive power or sprint, older atletes performed better, and estimates decreased with increasing event duration. One of the shortest events (1-5 s) are the athletics throws, where the need to precisely and rapidly perform a sequence of complex motor patterns clearly requires many years of training and experience to master (Hollings, 
Hopkins and Hume, 2014). Sport events being a little longer (10-55 s) are tipically track sprint events or short distance swimming, where the performance is more likely to depend on raw power than on aquisition and application of a specific skill (Hollings, Hopkins and Hume, 2014), explaining why younger athletes are more likely to win.

Aging is accounted for the natural decline of our capacites. Endurance athletes older than 40 years (,Masters”) show „exceptionally successful aging”, since many of them deliver impressive exercise performance and physiological parameters (Tanaka and Seals, 2008). Most of the winning times of the first modern Olympic games held in 1896 have been set by athletes older then 40 years old (the winning time of the marathon winner in $1896-$ who was 23 at that time - was even set by a 73 years old runner since then). The number of older adults participating in competitive events has increased in the past 100 years at a much greater rate than that of young adults. This, and the changes in training and nutritional practices together improved the peak performance of Masters athletes dramatically (Ericsson, 1993). It is known, that performance in long distance running - requiring endurance primarily - can be maintained until the age of 35 years approximately, and it only shows a slight reduction until 50-60 years of age, when the decline of performance becomes steeper (Tanaka and Seals, 2003).

The first comprehensive article of age of peak performance of top athletes was published in 1988 by Schulz and Curnow (Schulz and Curnow, 1988). They have noted that although the absolute levels of peak performance among the top athletes improved dramatically in the previous 100 years, the age at which peak performance was achieved had remained practically unchanged. They have also noticed that optimal age depended on the discipline, and they have mentioned that the age golf players, who reached their highest level of performance at the age of 31 years at that time, already showed a slight movement towards younger ages. They have estimated the age of competitors at their peak performance in sports requiring mostly sprint or explosive power to be at about the early twenties; while in sports requiring mostly endurance, practice, and learning to be at about the late twenties or even the early thirties. Since their work many researchers have suggested, that the peak performance of the top athletes is not exclusively determined by biological factors, but it is highly influenced by learning, experience, mental resilience, and motivation (Knechtle, Wirth and Rosemann, 2010); (Parry et al., 2011) which may culminate at much older ages than biological factors do. It is a common finding that the age of the best ultramarathon runners (any running distance longer than the classical marathon distance of $42.195 \mathrm{~km}$, like 50 miles, 100 miles, 24 h, 6 days or 10 days) increase with increasing race distance (Knechtle et al., 2014). The previus experience seems to be so dominant to succeed, that the number of finishes is one of the most important predictors for successful outcome in different ultra-endurance disciplines (Knechtle et al, 2011); (Hoffman and Parise, 2015). With increasing number of finishes in the same ultra-marathon distance, the performance is expected to improve although the athletes become older (Knechtle at al, 2014). Although the current study does not include ultra-endurance disciplines, the findings support these trends. The age of gold medal winner men of $100 \mathrm{~m}$ freestyle swimming (requiring sprint and explosive power mostly) in the period examined was $21.9 \pm 0.7$ years, compared to $28.6 \pm 1.3$ years, the age of gold medal winner sabreurs (sabre requires learning, practice, and experience mostly). It must be noted, though, that swimmers reach their peak performance much younger than athletes from most other sports, even from those requiring sprint and explosive power mostly. It is likely that extremely early specialisation contributes to the early peaking phenomenon observed in swimmers (Vaeyens et al. reported that 
among the Olympians of 2004 the mean age of specialisation was 8 years for swimmers, while it was 14 years for athletics competitors; (Vaeyens et al., 2009).

Rüst et al. (2014) studied a very similar question to ours: they determined the age and its changes across years of peak swimming performance for elite Swiss freestyle swimmers between 1994 and 2012. They investigated the association between age and swimming speed of the annual ten fastest men and women swimmers in each distances. For freestyle women, mean age of peak swimming speed increased in $50 \mathrm{~m}$ from 18.9 to 20.4 years, but decreased in $1500 \mathrm{~m}$ from 25.0 to 18.1 years, while it did not change significantly in 100-800 m distances. Men in peak swimming speed showed a tendency of "getting younger" in $50 \mathrm{~m}$ only, in all other distances the mean age at peak performance remained unchanged over the years. These results reveal that an investigation in a significantly shorter time period (16 years compared to 56), and although including a higher number of participants (70059 compared to 2205), but still limited to a single area (Switzerland compared to the international Olympic Games) observations might both agree $(50 \mathrm{~m}$ women $)$ or disagree $(50 \mathrm{~m} \mathrm{men})$ with ours.

The trend of the age of peak endurance performance increasing these last decades was examined by Gallmann et al. (Gallmanna et al., 2014). The age of the top ten triathletes in „Ironman Hawaii” (considered as the Ironman World Championship) was investigated between 1983 and 2012. They observed, that the age of elite triathletes, both men and women, increased over the last three decades, while their performances improved. The mean age of the annual top ten finishers increased from $26 \pm 5$ years to $35 \pm 5$ years for women and from $27 \pm 2$ years to $34 \pm 3$ years for men, while the overall race time decreased from $671 \pm 16$ min to $566 \pm 8$ min for women, and from $583 \pm 24 \mathrm{~min}$ to $509 \pm 6$ min for men. Ironman triathlons covering $3.8 \mathrm{~km}$ swimming, $180 \mathrm{~km}$ cycling and $42 \mathrm{~km}$ running represent endurance sports exceedingly, and since they are complex enough, their study is also suitable to reveal differences between the age of peak performance of various endurance disciplines. Considering the split disciplines, Gallmann et al. (2014) found the age to increase in all three disciplines, namely in swimming, in cycling, and in running, similarly in both genders, while the tendency to improve the performance was only apparent in the cycling and running split times for both men and women, swimming split time did not reduce for women (the latter might be related to the observation that the best female swimmers were significantly younger than the best cyclists).

Allen et al. (Allen, Vandenbogaerde, and Hopkins, 2014) employed a different method to describe the age of peak performance: they identified the age at which top athletes achieved their best performance. They searched for annual best times of male and female swimmers who were top 16 in pool events at the 2008 or 2012 Olympics, from each swimmer's earliest available competitive performance through to 2012. They have estimated the peak performance of male swimmers at the age of $24.2 \pm 2.1$ years, with $2.6 \pm 1.5$ years peakperformance window, which is in agreement with the observations regarding the age of male swimmers. According to Allen et al. (2014) female swimmers can achieve their peak performance at the age of $22.5 \pm 2.4$ years, and similar to men, their performance does not decline for another $2.6 \pm 1.5$ years. The significantly lower optimal age for female swimmers is also in accordance with the findings of this work.

The analysis of the Olympic disciplines covered by this study seems to outline an ,optimal” age: in those disciplines, in which the winners were younger than 26.1 years at the beginning of the examination period, the medallists became older over the decades. In those disciplines, however, in which the winners were older than 26.1 years at the 
beginning of the examination period, younger and younger athletes won their Olympic medals as time went by. Some data suggest, that the age of 26.1 years might be a "universal optimal age" in humans. Berthelot et al. (2012) estimated the age of peak performance of the world's best athletes, swimmers, and chess players being at 26.1 years. This observation might be explained by biological and physiological factors which peak at similar age, such as pulmonary functions (Schoenberg, Beck and Bouhuys, 1978), cognitive capacity (Salthouse, 2009), reproductive functions (Kühnert and Nieschlag, 2004), or peak bone mineral density (Boot et al., 2010).

It has to be mentioned, though, that while the age, and the trend in changes of the age of the medallists in the disciplines examined in this work perfectly matches the theory presuming the presence of an optimal age, certain disciplines surely do not follow such patterns. Counterexamples are easiest to demonstrate among ultradistance competitors (Knechtle et al., 2014); (Hoffman and Parise, 2015); (Gallmann et al., 2014); (Hoffman and Wegelin, 2009). Overall, peak performance in endurance events is probably reached at much older ages than in explosive power/ sprint events.

\section{Acknowledgement}

Neither the authors nor the employers of the authors have any financial interest in or a financial conflict with the subject discussed in this article.

The work was supported by the GINOP-2.3.215-2016-00062 project. The project is co-financed by the European Union and the European Regonal Development Fund.

\section{References}

Berthelot G., Len S., Hellard P., Tafflet M., Guillaume M., Vollmer J.C., Gager B., Quinquis L., Marc A., \& Toussaint J.F. (2012). Exponential growth combined with exponential decline explains lifetime performance evolution in individual and human species. AGE, 34(4): 1001-9.

Simonton D.K. (1988). Age and outstanding achievement: what do we know after a century of research? Psychol Bull, 104: 251-67.

Allen S.V., \& Hopkins W.G. (2015). Age of Peak Competitive Performance of Elite Athletes. A Systematic Review. Sports Med, 45: 1431-41.

Berthelot G., Thibault V., Tafflet M., Escolano S., El Helou N., Jouven X., Hermine O., \& Toussaint J.F. (2008). The citius end: world records progression announces the completion of a brief ultra-physiological quest. PLoS ONE, 3(2):e1552. doi:10.1371/journal.pone.0001552.

Hollings S.C., Hopkins W.G., \& Hume P.A. (2014). Age at peak performance of successful track and field athletes. In J Sports Sci Coach, 9: 651-62.

Tanaka H., \& Seals D.R. (2008). Endurance exercise performance in Masters athletes: ageassociated changes and underlying physiological mechanisms. J Physiol, 586(1): 55-63.

Ericsson K.A. (1993). Peak performance and age: an examination of peak performance in sports. In: Successful Aging: Perspectives from the Behavioral Sciences. eds Baltes P.B., Baltes M.M. New York, NY: Cambridge University Press, 164-96.

Tanaka H., \& Seals D.R. (2003). Invited Review: Dynamic exercise performance in Masters thletes: insight into the effects of primary human aging on physiological functional capacity. $J$ Appl Physiol, 95(5): 2152-62.

Schulz R., \& Curnow C. (1988). Peak performance and age among superathletes: track and field, swimming, baseball, tennis, and golf. J Gerontol, 43: 113-20.

Knechtle B., Wirth A., \& Rosemann T. (2010). Predictors of race time in male ironman triathletes: physical characteristics, training, or prerace experience? Percept Mot Skills, 111: 437-46. 
Parry D., Chinnasamy C., Papadopoulou E., Noakes T., \& Micklewright D. (2011). Cognition and performance: anxiety, mood and perceived exertion among Ironman triathletes. $\mathrm{Br} J$ Sports Med, 45: 1088-94.

Knechtle B., Valeri F., Zingg M.A., Rosemann T., \& Rüst C.A. (2014). What is the age for the fastest ultra-marathon performance in timelimited races from $6 \mathrm{~h}$ to 10 days? AGE, 36: 9715.

Knechtle B., Knechtle P., Rosemann T., \& Lepers R. (2011). Personal best marathon time and longest training run, not anthropometry, predict performance in recreational 24-hour ultrarunners. J Strength Cond Res, 25: 2212-8.

Hoffman M.D., \& Parise C.A. (2015). Longitudinal assessment of age and experience on performance in 161-km ultramarathons. Int $J$ Sports Phys Perf, 10(1): 93-8.

Vaeyens R., Güllich A., Warr C.R., Philippaerts R. (2009). Talent identification and promotion programmes of Olympic athletes. I Sports Sci, 27: 1367-80.

Rüst C.A., Knechtle B., Rosemann T., \& Lepers R. (2014). The changes in age of peak swim speed for elite male and female Swiss freestyle swimmers between 1994 and 2012. J Sports Sci, 32(3): 248-58.
Gallmann D., Knechtle B., Rüst C.A., Rosemann T., \& Lepers R. (2014). Elite triathletes in Ironman Hawaii' get older but faster. AGE, 36: 407-16.

Allen S.V., Vandenbogaerde T.J., \& Hopkins W.G. (2014). Career performance trajectories of Olympic swimmers: benchmarks for talent development. Eur J Sport Sci, 14(7): 643-51.

Schoenberg J.B., Beck G.J., \& Bouhuys A. (1978). Growth and decay of pulmonary function in healthy blacks and whites. Respir Physiol, 33: 367-93.

Salthouse T.A. (2009). When does age-related cognitive decline begin? Neurobiol Aging, 30: 50714.

Kühnert B., \& Nieschlag E. (2004). Reproductive functions of the ageing male. Hum Reprod Update, 10: 327-39.

Boot A.M., de Ridder M.A.J., van der Sluis I.M., van Slobbe I., Krenning E.P., \& de Muinck Keizer-Schrama S.M.P.F. (2010). Peak bone mineral density, lean body mass and fractures. Bones, 46: 336-41.

Hoffman M.D., \& Wegelin J.A. (2009). The Western States 100-Mile Endurance Run: participation and performance trends. Med Sci Sports Exerc, 41: 2191-8. 